\title{
Toward Educational Equity for Ethnic Groups in the Highlands of Northern Thailand: A Study of Comprehensive Humanity
}

\author{
Chayanid Yimsawat ${ }^{1 *}$, Charin Mangkhang ${ }^{1}$, Bupa Anansuchatkul', \\ and Thongchai Phuwanatwichit ${ }^{2}$
}

\author{
${ }^{1}$ Faculty of Education, Chiang Mai University, Chiang Mai 50200, Thailand \\ ${ }^{2}$ Faculty of Humanities, Chiang Mai University, Chiang Mai 50200, Thailand \\ *Corresponding author. E-mail: Chayanid.y@cmu.ac.th \\ https://doi.org/10.12982/CMUJASR.2019.0010
}

\begin{abstract}
This article studied the characteristics of comprehensive humanism and reviewed the education management approach to equality for ethnic groups in Northern Thailand through the basic education provided by the Thai government. A qualitative research method was employed, using content analysis. The participants comprised fifteen undergraduate students from ethnic minorities and six teachers from private and public schools, using volunteering sampling. The results of the literature review showed that comprehensive humanism refers to the state of a person that is complete in terms of cognitive, emotional, and behavioral abilities, able to understand themselves and others, and has respect for human rights in a diverse society. It was found that locality and ethnicity are vaguely identified in the Thai national curriculum. Many indicators illustrate that the curriculum focuses on monoculturalism, with an emphasis on Thai national identity and culture. Moreover, the perspectives of ethnic groups were collected via group dialogues involving students from ethnic minorities. Undergraduate students from upland ethnic minorities stated that the lowland ethnic groups treated them differently from their peer groups. Teachers' teaching methodology and textbooks failed to contribute to an understanding and acceptance of their different ethnicities. The findings reflect an inequality in education in the social context of diverse ethnic groups that impedes comprehensive humanization in terms of cognitive, emotional, and behavioral abilities. The data from the study can be used as a guide to design educational management or organize activities that promote understanding of ethnic 'others' to encourage the development of children so that they become comprehensive citizens in the future.
\end{abstract}

Keywords: Curriculum, Education, Equity, Ethnic minority, Humanism

\section{INTRODUCTION}

Globalization leads to the cultural and economic influences of developed countries flooding into other countries, including Thailand, so that Western norms dominate the thoughts and living conditions of many non-western people (Kroeksakul, Naipinit, and Na Sakolnakorn, 2014). Ponting (1991) argues that the 'idea of progress' is an important element of modern education, leading to the exploitation of resources and economic competition, regardless of the negative impact on society. Mangkhang (2017) maintains that Thai education is founded on an ideology 
based in Western culture, one which focuses on competition to meet the demands of materialism and consumerism, and which may result in people not respecting the rights of others.

To overcome an exploitative and materialistic conception of education, an educational ideal based on the notion of human development is crucial. For example, Rukspollmuang (2014) argues that education is a process which starts from basic knowledge and thought but which is directly linked to the development of a whole person and focuses on all-around human development. Phra Dhammapitaka (2013) postulates that there are three aspects to human development, the cognitive, emotional, and behavioural. Cognitively, students should be able to recognize, analyze, and develop discriminatory powers so that they can assess information. One can educate the emotions to present a positive attitude to others, and behaviorally, one should possess the ability to understand and respect differences in a multicultural society. This is in accordance with UNESCO's development guidelines which emphasize establishing a knowledge society through education to be connected with cultural diversity. A part of UNESCO's plan of action needs to improve the curriculum and historical textbooks, and enhances the understanding of languages and international cultures in order to create peace and respect to each other (UNESCO, n.d.).

The latter ability is crucial, as Thai society is a multicultural society comprising over 62 ethnolinguistic groups, including nearly 40 million people from ethnic minorities. According to the government's Master Plan for the Development of Ethnic Groups in Thailand 2015-2017 (2016) and the International Convention on the Elimination of All Forms of Racial Discrimination (2011), there are approximately 6.1 million people from ethnic groups in Thailand, distributed across various areas. Most of the population from ethnic groups are settled on plains and in general live in relative peace with Thai people. However, other ethnic groups live in mountainous areas and are known as the mountain peoples. Most mountain peoples live in Northern Thailand and are divided into 13 groups: Karen, Hmong (Maew), Yao (Mien), Lisu (Lisaw), Lahu (Muso), Akha (Ikho), Lua, Thin, Khmu, Chin Haw, Tongsu, Kachin, and Palaung (Ta'ang).

So far, Thai education management has been unable to facilitate human development following specific, ethnic, social conditions, as the national curriculum focuses on meeting mainstream cultural norms. As a result, segregation and racism are rampant in Thai schools, leading to greater social class and ethnic cleavages. This is particularly true in Northern Thailand, where there is a large number of ethnic groups. Considering equality and equity, equality means treating everyone the same (sameness). Individual differences, such as gender, race, religion, language, and so forth cannot be used as an excuse for discrimination. Equity means treating people based on criteria such as status, education, and income. For example, lower class individuals should get more financial support from the state than middle class individuals, for instance through poverty relief. Differential treatment may lead to inequalities in treating individuals, but this eventually leads to greater equity (Kurian, 2011; Pituktanin, 2014; Suntonanantachai, 2016; Mansap, n.d.). In Thailand, education provides an equal opportunity for everyone in principle. In practise, however, the curriculum, textbooks, and materials are not tailored towards, beneficial for, or effective in terms of educational outcomes for ethnic groups.

Given Thailand's ethnic diversity, it is important to ask whether Thai education management can successfully meet the requirements of a multicultural society. Anansuchatkul (2011) studied the education of stateless children. She found that personnel in most schools and communities lack the sorts of understanding that would promote harmonious co-existence of 
people from different cultures. Many school personnel hold negative attitudes towards stateless children. Although on paper, all children are educated 'equally', stateless children were nonetheless discriminated against, creating educational inequity and violating their human rights. Such inequities affect their cognitive, emotional, and behavior abilities, and generally impede human development.

The purpose of this article is twofold. First, we want to review the guidelines for the administration of the basic education curriculum in Northern Thailand and reflect on how these guidelines affect the education of students from ethnic minorities. Second, we want to guide educators so that they can better manage education in a multicultural society and encourage citizens from diverse backgrounds to coexist peacefully.

\section{METHODOLOGY}

This research employed qualitative content analysis by consulting the work of Phra Dhammapitaka, 2013, a recognized and well-known human developer in Thailand, the UNESCO Global Citizenship Development concept, 2015, the ASEAN Citizenship Concept, SEAMEO, 2010, \& the Earth Charter, 2018. The result was that comprehensive human characteristics can be divided into three aspects: the cognitive, emotional, and behavioural. Each aspect comprises a critical part of comprehensive humanization.

To further inform these three aspects, 61 related works were analysed. They derive from four theories of education: 1) confucian, 2) contemplative, 3) neo-humanist, and 4) andragogy, involving five monks, four philosophers and spiritual leaders, two developers of quality of life, seven scholars, twenty two contemplative education researchers, three andragogy researchers, and fourteen neo-humanist researchers.

After summarizing the characteristics of a comprehensive human, the data were compared with the national education core curriculum and the curriculum of the subject of citizenship education (added in 2014) to analyze the government education management guidelines that have impeded the development of Thai citizens as comprehensive humans.

The data and the problems were brought to the attention of a dialogue group of students from ethnic minorities in Northern Thailand. Fifteen students participated in the talk through volunteering sampling. They comprised three Hmong students, one Lua student, one Akha student, one Lahu student, seven Karen students, and two Shan students, from Chiang Rai, Chiang Mai, Nan, Mae Hong Son, and Lamphun. These students were studying at the undergraduate level, and all of them embodied specific ethnic characteristics and came from similar social backgrounds. The discussion emphasized drawing conclusions by inductive reasoning (Lodico, Spaulding, and Voegtle, 2006; Paul \& Ormrod, 2013; Mills \& Gay,, 2019). Data analysis also derived from a group discussion and in-depth unstructured interviews with six teachers in public and private schools, by phone interviews and face-to-face conversations. These were volunteer participants.

\section{Analysing the definition of a comprehensive human}

The definition of a comprehensive human combines Eastern and Western concepts by comparing the comprehensive human development system of Phra Dhammapitaka (2013) with the UNESCO Global Citizenship Development concept (2015), the ASEAN Citizenship concept, 
and the Earth Charter. The Phra Dhammapitaka and the Global Citizenship development are similar approaches, in that they both emphasize cognitive, emotional and behavioral aspects.

We concluded that the cognitive aspect comprised of 1) reasonable linkage analysis, 2) information literacy, 3) knowledge adaptation, and 4) knowledge sharing.

The emotional aspect comprised of 1) positive attitudes towards others, 2) public mind 3) conscience and 4) moral integrity.

The behavioral aspect comprised of 1) realization of one's rights and duties and those of others, 2) understanding social diversity, 3) compliance with regulations, 4) engagement in social activities, 5) restraining from violence, and 6) environmental conservation.

The analytical approaches can be examined from Table 1 as follows:

Table 1. Frequency analysis of the characteristics of a comprehensive human classified by the groups of informants.

\begin{tabular}{|c|c|c|c|c|c|c|c|c|c|c|c|c|c|c|c|}
\hline \multirow{3}{*}{$\begin{array}{l}\text { Group of } \\
\text { informants }\end{array}$} & \multirow{3}{*}{ 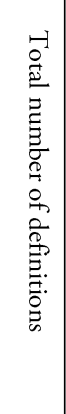 } & \multicolumn{14}{|c|}{ Definitions of the characteristics of a comprehensive human } \\
\hline & & \multicolumn{4}{|c|}{ Cognitive } & \multicolumn{4}{|c|}{ Emotional } & \multicolumn{6}{|c|}{ Behavioral } \\
\hline & & 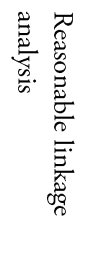 & 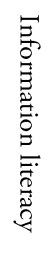 & 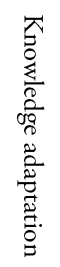 & 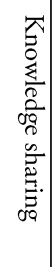 & 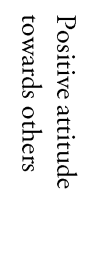 & 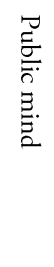 & 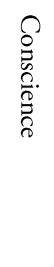 & 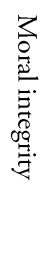 & 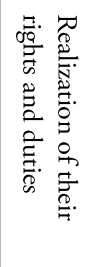 & 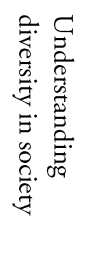 & 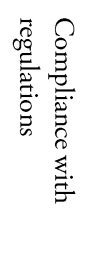 & 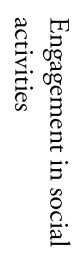 & 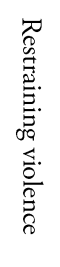 & 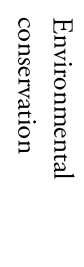 \\
\hline $\begin{array}{l}\text { Theoretical } \\
\text { concepts }\end{array}$ & 4 & 4 & 1 & 4 & 4 & 3 & 3 & 4 & 3 & 4 & 2 & 3 & 4 & 3 & 2 \\
\hline Monks & 5 & 4 & 4 & 5 & 2 & 5 & 3 & 5 & 5 & 1 & 0 & 2 & 3 & 2 & 2 \\
\hline $\begin{array}{l}\text { Philosophers \& } \\
\text { Spiritual leaders }\end{array}$ & 4 & 4 & 2 & 3 & 2 & 3 & 3 & 3 & 4 & 2 & 2 & 0 & 3 & 3 & 1 \\
\hline Developers & 2 & 1 & 1 & 0 & 0 & 1 & 2 & 1 & 1 & 2 & 1 & 0 & 2 & 0 & 0 \\
\hline Scholars & 7 & 6 & 4 & 4 & 1 & 4 & 4 & 4 & 6 & 3 & 3 & 2 & 5 & 4 & 3 \\
\hline $\begin{array}{l}\text { Contemplative } \\
\text { education } \\
\text { researchers }\end{array}$ & 22 & 18 & 12 & 12 & 11 & 19 & 14 & 11 & 11 & 14 & 8 & 7 & 13 & 6 & 7 \\
\hline $\begin{array}{l}\text { Andragogy } \\
\text { researchers }\end{array}$ & 3 & 2 & 1 & 2 & 2 & 1 & 1 & 1 & 0 & 2 & 2 & 1 & 1 & 0 & 0 \\
\hline $\begin{array}{l}\text { Neo-humanist } \\
\text { researchers }\end{array}$ & 14 & 9 & 4 & 10 & 3 & 10 & 7 & 9 & 11 & 6 & 1 & 3 & 10 & 11 & 2 \\
\hline Total & 61 & 47 & 29 & 40 & 25 & 46 & 37 & 38 & 41 & 34 & 19 & 18 & 41 & 29 & 17 \\
\hline Percentage & 100 & 77 & 48 & 66 & 41 & 75 & 61 & 62 & 67 & 56 & 31 & 30 & 67 & 48 & 28 \\
\hline
\end{tabular}

The characteristics of each aspect were used to compare the 61 works on the characteristics of a comprehensive human, and it was found that the comprehensive human characteristics of analytical thinking skills and positive attitude towards others are most frequently mentioned, at 77 percent and 75 percent, respectively. The characteristics with 60 percent or more are engagement in social activities and knowledge adaptation, whereas the least mentioned characteristic is 
environmental conservation, at 28 percent. The findings of this analysis indicated that the four groups of theoretical concepts mentioned similar characteristics in every aspect. The main remarks are the contemplative education concept and the neo-humanist concept. The first one is a concept that focuses on all-around human development, whereas the second concept does not mention restraining violence and environmental conservation. ${ }^{1}$ the researchers noted that the human development methods of contemplative education and neo-humanist are similar in the matter of emotional development of humans. The difference in the concept of neo-humanism is its main focus is on brain development. It was also found that the monk group focused mainly on the cognitive and emotional development of humans. Moreover, it was found that based on the characteristic analysis, the National Basic Education Core Curriculum mentioned various aspects of the characteristics of comprehensive humans. It emphasized understanding and positive attitudes towards others. However, it was found that understanding problems and racial discrimination still occur in ethnically diverse classrooms.

According to the information acquired, the researcher investigated the Thai government's education management guidelines through the National Basic Education Core Curriculum and the additional subject of the citizenship education curriculum. The details are in Table 2. (Office of the Basic Education Commission, 2008; 2014)

Table 2. Analysis of the basic education curriculum 2008 and the additional subject of citizenship education curriculum 2014.

\begin{tabular}{|c|c|c|c|c|c|c|}
\hline Level & $\begin{array}{l}\text { Basic education core } \\
\text { curriculum (2008) }\end{array}$ & Mentioned & Unclear & $\begin{array}{l}\text { Citizenship education } \\
\text { curriculum (2014) }\end{array}$ & Mentioned & Unclear \\
\hline Grade 1 & $\begin{array}{l}\text { Indicator } 1 \text { Specify the } \\
\text { advantages and be a } \\
\text { good member of the } \\
\text { family and the school } \\
\text { Indicator } 2 \text { Cite } \\
\text { examples of their own } \\
\text { goodness and that of } \\
\text { others and tell the } \\
\text { effects of that goodness }\end{array}$ & & $\sqrt{ }$ & $\begin{array}{l}\text { Accept their differences } \\
\text { and those of others }\end{array}$ & $\sqrt{ }$ & \\
\hline Grade 2 & $\begin{array}{l}\text { Indicator } 2 \text { Observe } \\
\text { Thai manners } \\
\text { Indicator } 3 \\
\text { Demonstrate the } \\
\text { behavior of accepting } \\
\text { the different thoughts, } \\
\text { beliefs, and practices of } \\
\text { others without prejudice }\end{array}$ & $\sqrt{ }$ & $\sqrt{ }$ & $\begin{array}{l}\text { Accept their differences } \\
\text { and those of others }\end{array}$ & $\sqrt{ }$ & \\
\hline Grade 3 & $\begin{array}{l}\text { Indicator } 2 \text { Tell their } \\
\text { own behavior in life and } \\
\text { that of others in the } \\
\text { context of diversified } \\
\text { cultures }\end{array}$ & $\sqrt{ }$ & & $\begin{array}{l}\text { Accept and coexist } \\
\text { with others in peace }\end{array}$ & $\sqrt{ }$ & \\
\hline Grade 4 & $\begin{array}{l}\text { Indicator } 4 \text { Explain the } \\
\text { cultural differences of } \\
\text { various groups of people in } \\
\text { the locality }\end{array}$ & 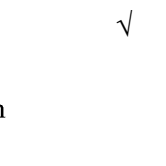 & & $\begin{array}{l}\text { Accept and coexist } \\
\text { with others in peace } \\
\text { and interdependence }\end{array}$ & $\sqrt{ }$ & \\
\hline
\end{tabular}

\footnotetext{
${ }^{1}$ See appendix
} 
Table 2. Continued.

\begin{tabular}{|c|c|c|c|c|c|c|}
\hline Level & $\begin{array}{l}\text { Basic education core } \\
\text { curriculum (2008) }\end{array}$ & Mentioned & Unclear & $\begin{array}{l}\text { Citizenship education } \\
\text { curriculum (2014) }\end{array}$ & Mentioned & Unclear \\
\hline Grade 5 & $\begin{array}{l}\text { Indicator } 3 \text { Appreciate the } \\
\text { values of Thai culture that affect } \\
\text { the way of life in Thai society }\end{array}$ & & $\sqrt{ }$ & $\begin{array}{l}\text { Accept diverse cultures } \\
\text { and society in the locality, } \\
\text { and coexist with others in } \\
\text { peace and } \\
\text { interdependence }\end{array}$ & $\sqrt{ }$ & \\
\hline Grade 6 & $\begin{array}{l}\text { Indicator } 2 \text { Analyze cultural } \\
\text { change over time and preserve } \\
\text { fine culture } \\
\text { Indicator } 3 \text { Show Thai manners } \\
\text { appropriate to the occasion } \\
\text { Indicator } 4 \text { Explain the different } \\
\text { cultural values of various groups } \\
\text { of people in Thai society }\end{array}$ & $\sqrt{ }$ & $\sqrt{ }$ & $\begin{array}{l}\text { Accept diverse cultures } \\
\text { and society in Thailand } \\
\text { and coexist with others in } \\
\text { peace and } \\
\text { interdependence }\end{array}$ & $\sqrt{ }$ & \\
\hline Grade 7 & $\begin{array}{l}\text { Indicator } 3 \text { Discuss cultural } \\
\text { values conducive to creating } \\
\text { harmonious relations or mutual } \\
\text { understanding } \\
\text { Indicator } 4 \text { Show respect for } \\
\text { their own rights and freedoms } \\
\text { and those of others }\end{array}$ & $\sqrt{ }$ & $\sqrt{ }$ & $\begin{array}{l}\text { Accept diverse culture } \\
\text { society in Southeast Asia } \\
\text { and coexist with others in } \\
\text { peace and } \\
\text { interdependence }\end{array}$ & $\sqrt{ }$ & \\
\hline Grade 8 & $\begin{array}{l}\text { Indicator } 2 \text { Appreciate the value } \\
\text { of self-conduct in accord with the } \\
\text { status, roles, duties, freedoms, } \\
\text { and duties of good citizens along } \\
\text { the democratic path } \\
\text { Indicator } 4 \text { Explain similarities } \\
\text { and differences between Thai } \\
\text { culture and the cultures of other } \\
\text { countries in the Asian region } \\
\text { conducive to creating mutual } \\
\text { understanding }\end{array}$ & & $\sqrt{ }$ & $\begin{array}{l}\text { Value coexistence with } \\
\text { others in Asia in peace } \\
\text { and interdependence }\end{array}$ & $\sqrt{ }$ & \\
\hline Grade 9 & $\begin{array}{l}\text { Indicator } 2 \text { Participate in } \\
\text { protecting others in accordance } \\
\text { with the principles of human } \\
\text { rights } \\
\text { Indicator } 3 \text { Conservation of } \\
\text { Thai culture and adoption of } \\
\text { international culture }\end{array}$ & $\sqrt{ }$ & $\sqrt{ }$ & $\begin{array}{l}\text { Value coexistence with } \\
\text { others in different regions } \\
\text { of the world in peace and } \\
\text { interdependence }\end{array}$ & $\sqrt{ }$ & \\
\hline $\begin{array}{l}\text { Grade } \\
10-12\end{array}$ & $\begin{array}{l}\text { Indicator } 3 \text { Conduct themselves } \\
\text { and participate in encouraging } \\
\text { others to conduct themselves to } \\
\text { become good citizens of the } \\
\text { nation and the world community } \\
\text { Indicator } 4 \text { Evaluate human } \\
\text { rights situations in Thailand and } \\
\text { propose developmental } \\
\text { guidelines } \\
\text { Indicator } 5 \text { Analyze the necessity } \\
\text { to improve, change and preserve } \\
\text { Thai culture and choose to } \\
\text { absorb universal culture }\end{array}$ & $\sqrt{ }$ & $\sqrt{ }$ & $\begin{array}{l}\text { Accept identity and } \\
\text { respect the diversity of the } \\
\text { multicultural society and } \\
\text { value coexistence with } \\
\text { others in peace and } \\
\text { interdependence }\end{array}$ & $\sqrt{ }$ & \\
\hline Total & 19 & & 12 & 10 & 10 & - \\
\hline
\end{tabular}

Sources: Office of the Basic Education Commission (2008) and Office of the Basic Education Commission (2014). 


\section{State ideology: The inaccurate concept of education management to create citizenship}

The results of the analysis of basic education management curriculum regarding the aspect of understanding and acting on the duties of a good citizen found that it comprised of good values and maintaining Thai tradition and culture, and coexisting in Thai society and the world peacefully (Office of the Basic Education Commission, 2008). There are 19 related indicators. The curriculum mentioned the equity of the ethnic group students with 7 clear indicators and 12 indicators which have no proof of the equity. There was little equity for Thailand's ethnic groups. The researchers noted that unclear indicators would hinder the understanding of ethnic diversity. The analysis showed that the indicators focused on Thai culture, which emphasizes the development of the lowland ethnic groups. Therefore, the national education management approach led to human rights violations, such as discrimination against individuals from different ethnic or religious backgrounds (Anansuchatkul, 2011).

The indicators that identified coexistence did not mention the term 'ethnic group' but mainly focused on respecting human rights and different cultures among 'local' people. According to the information from the interviews with the teachers, it was found that they did not explain the awareness of the rights of the various ethnic groups. This, therefore, reflected that the teachers could not teach the students based on the understanding of multicultural society.

In 2014, the Thai government mandated a new citizenship education subject curriculum Its focus is on reconciliation, harmony and coexistence in a diverse society (Office of the Basic Education Commission, 2014). The government had intended promoting equity for ethnic groups in Thailand and Asia. The citizenship curriculum is the starting point for furthering understanding and equity. It is of some concern that most teachers in Thailand were educated before the citizenship curricular initiatives of 2014. This may cause a lack of understanding of the importance of conveying cultural knowledge about different ethnic groups properly, which in turn may lead to educational inequity.

\section{Educational equity of ethnic groups in the highlands of Northern Thailand}

In the highlands of northern Thailand, there exist more ethnic groups that are being educated together with lowland ethnic groups than in any other part of Thailand Education management is required to take ethnic diversity into account. Nevertheless, the basic education management curriculum and the teachers fail to promote understanding and coexistence in a multicultural society, leading to educational inequity.

The researchers applied the techniques of knowledge management (Faul \& Camacho, 2004; Ramalingam, 2006; Young and Asian Productivity Organization, 2010) to conduct a group discussion with ethnic students, all of whom were educated through the basic education core curriculum. The participants were three Hmong students, one Lua student, one Akha student, one Lahu student, seven Karen students, and two Shan students, from Chiang Rai, Chiang Mai, Nan, Mae Hong Son, and Lamphun. The research was conducted in October 2018 and again in August 2019.

The students combined their retrospective views with storytelling to provide a comprehensive picture of their experiences of school life in a diverse campus, one requiring interaction with other people in lowland society. Participants used a Knowledge Café to exchange information and facilitate a dialogue. The researcher adopted a conversational approach and recorded the conversations by placing a mobile phone in the middle of the group. We used a pen 
and a notebook to take important notes. All reasonable steps were taken to discover the truths of a different and complex society (Patton, 1980).

Throughout, the researchers ensured that there existed informed consent, protection from harm, and confidentially for the sample groups (Lodico, Spaulding, and Voegtle, 2006). In group conversations, the main issues were recorded by verbatim transcription.

\section{RESULTS}

\section{Following is a summation of our major findings.}

1. Teachers lacked the sensitivity to focus on diverse ethnic groups of students. They were unable to interpret the curriculum to teach effectively in a multicultural classroom. As the students reflected: "When I was at school, teachers did not understand the word ethnicity. Some teachers didn't even know what my ethnicity is..." (Hmong, a first-year student) "Sometimes, teachers are not local people. Some teachers understand, and some teachers don't understand. They only teach the information that exists in the textbook..." (Lua, a third-year student) "A teacher in a general school wouldn't understand and would never talk about ethnicit. But at my school, a new teacher did not understand. Later, he started to understand, but never mentioned it in the classroom..." (Hmong, a second-year student).

The information indicates that the teachers adhered to the education management of teaching materials that follows the textbook's content to allow the students to meet the state's educational standards, and no more.

The students reflected on the academic preparation of their teachers:

The teachers rarely or never talked about ethnicity. When it's time to talk about equity, the teachers only talked about what anyone can do, such as queuing. On the matter of rights, the teachers only talked about what everyone can see, but never talked about the rights of ethnic groups... (Akha, a second-year student)

When we studied the additional subject of citizenship (2014), the teachers never talked about ethnicity. They only talked about goodness, the 12 Core Values of Thai People given by the government, and discipline. No teacher talked about ethnic diversity... (Karen, a third-year student)

When the teachers saw me reading a book, the teachers would ask if the book will be useful for the exam. When I read a book, I did not think about that. I read it because I was interested in it. The teachers overlooked this and focused only on the exam. I think this might be caused by the educational system... (Hmong, a third-year student)

The textbook emphasized knowledge about mainstream Thai culture. Ethnic diversity was not mentioned, and teachers ignored this important issue. One of the Hmong students stated:

The teachers never talked about my ethnicity. Maybe it was because the textbook only mentioned Thai culture in each region. The teachers only talked about lowland people. I didn't understand as I am Thai, but I felt like I don't exist...

There were many issues in the textbook that the students talked about. One of the Shan students reflected: 
No one can clearly define the words 'equity' or 'equality' in the textbook, and my education did not promote people to think. The textbook did not mention ethnic diversity. The textbook mostly mentioned Central Thailand. It did not support ethnic contexts, as it should have done. Then how can we understand each other...

Textbooks need to become more contemporary so that they are appropriate for learning in a multicultural society. One of the Karen ethnic students suggested:

The textbook has a significant influence on the creation of space and understanding. The lesson content should mention more about other ethnic groups. It would be great if the government needed to promote understanding among the teachers or organized additional teacher training for them to obtain more knowledge about ethnic groups in Thailand...

Teaching and learning management should encourage all teachers to learn more about other ethnic groups. One of the Karen ethnic students noted: "All parties involved in the educational system need to emphasize these matters. An additional teacher training session was organized as it was written in the curriculum, but it was ignored ..."

2. The social studies course aimed at memorized knowledge rather than the development of applied knowledge or thinking abilities, nor did it focus on the issues of coexistence in a diverse society. As one of the Karen ethnic students suggested: "...Studying in high school was full of irrelevant content; it was impossible to create understanding about ethnicity...”

This was consistent with the Akha student who stated:

Yes, there was a lot of content in social studies. It's like they put everything all together. The only purpose was to pass the exam. The subject of citizenship only mentioned things that would be in the exam. If it was unnecessary, the teachers would never talk about it. The teachers never talked about ethnicity...

The information suggests that there needs to be improvement to meet the goal of equity. Although the education management of the government promotes the goal of equity, there were nonetheless lots of gaps. The researchers noted that if teachers had a good understanding of ethnicity and ethnic diversity, they would be able to interpret the indicators in the national education management curriculum and associate the goals with the content in the lesson. A textbook that mentions ethnic diversity will help the teachers to be more aware of the issues and promote the understanding and study of ethnic groups.

\section{Ethnicity and classes in a classroom: The lesson of pain through the inequity of state education}

Maintaining the ethnic rights or the rights of local indigenous peoples or cultural groups should promote the coexistence of a diverse society. However, in practice, we found that the idea of a multicultural society is a highly abstract ideal, one that sometimes has little effect on the conduct of students in the classroom (Saiphan, 2014). For example, one of the Karen ethnic students commented:

... When I first attended high school, my friends did not know that I was an ethnic highlander. They treated me normally. Soon, my friends realised that I am an ethnic highlander. They changed. If there was something, they would let me choose later. I became a lower-class kid in their eyes. When it was time to clean up the classroom, they never did 
the cleaning. They left it for me to clean up the mess. It's like they pushed me lower than them...

One of the Hmong ethnic students talked about a similar kind of bullying:

... When I moved to study in an elementary school in the city, I was bullied because my surname is 'Sae' (which defines my ethnicity). When my friends knew, I was mocked, "You Maew Maew Maew" [insulting term for Hmong ethnic group]. When one of my friends or anyone did something strange, they would mock them as 'Maew'. I was pressured. Everyone was mocking me. I went to consult my mom and asked her to change our surname so that the others would stop mocking us. My mom agreed and changed our surname, and moved me to a new school...

Similarly, another Karen ethnic student commented:

...It's like discrimination in another discrimination. For example, if someone dressed up weirdly, the person would be mocked as "dressing like Yang" [dressing like an ethnic Karen person]. They want to mock the badly dressed guy, but they use our ethnic name as an insult...

The Hmong ethnic student added:

...It's not just the lowland people who discriminated against my ethnicity. My fellow ethnic people from other tribes also discriminated against each other. Perhaps we have to realize that education should take address this matter more seriously...

In sum, the ethnic students indicated that school and classroom contexts do not recognize ethnic diversity. Anan Ganjanapan (n.d) stated said that multiculturalism, in the context of a national state, tries to distinguish and define the fixed characteristics of ethnicity. Furthermore, the ethnic majorities possess the land by creating a dominant identity to oppress ethnic minorities. The Thai textbook and teachers adhere to Thai nationalism, which in turn causes discrimination in the classroom and social disharmony.

One of the Karen ethnic students confirmed this:

...My high school friends often called me 'E-Yang' [insulting terms for Karen ethnic group], and a lot of harsh words followed. I didn't like that, so I hit them. I told themBehold, I will get the highest scores in class and make you know that you are lower than me...

As this brief episode illustrates, racial discrimination can lead to violence. Also, the pain experienced by many ethnic students leads them to conceal their identities. One of the Karen ethnic students stated:

...Our ethnic friends rarely show their identities. They are afraid of others, knowing that they are ethnic highlanders. I assume from my experience that our friends are afraid to show their identities because they have been bullied. If they express their opinion, the lowland people rarely accept their opinion. It might be better to stay quiet...

The Akha student underscored this issue: “...I accepted that if I could choose, I would rather not reveal my identity. Because when I tell friends, I don't know how they will treat me..." 
The Lahu student stated: “...When I studied with students from other faculties or majors, if they did not ask, I would not express my identity. I have not so much to be proud of...”

These are the reflections of ethnic children who have studied in the classrooms in the highlands of Thailand. This problem or racial discrimination should be made obvious to everyone as it should never happen to any of our fellow humans or to people from any ethnic background. We should not let them face this inequity anymore.

Teachers: Reflection of education management by the Thai government

From these student reflections, it is clear that education management lacks an understanding of ethnic diversity. This was confirmed by interviewing a group of teachers in public and private schools in Northern Thailand.

A teacher in a lowland public school reflected on his school:

...My fellow teachers did not care about ethnic people. The national education management curriculum (2008) did not mention it. Although the citizenship education curriculum (2014) identified the creation of understanding of the multicultural society, none of my fellow teachers talked about the issue with their students. Some teachers misunderstood the word 'ethnic' with highlanders, although they are also ethnic people. I think that they did not focus on this issue because they were never aware or had little knowledge of these matters. Some teachers do not understand; therefore, they avoid teaching about this issue. Some teachers even discriminated against ethnic highlanders...

This sentiment is consistent with that of a private school teacher in Chiang Mai:

... When I was teaching about Thai culture and local culture, I never mentioned the ethnic people. It was not mentioned in the textbook. I did not interpret the curriculum that deep. I did not care much. Most of our students are not ethnic highlanders. I think some students did not even know any ethnic groups of highlanders...

A teacher in a public school in Northern Thailand noted:

... The basic education curriculum (2008) is a curriculum that allowed schools to provide more material subjects. It provides more management following local education. But, the problem is that the teachers are not local people. The teachers lack local knowledge, together with the ineffective management. Therefore, it is not as successful as it should be...

The data from our study suggests that education management is not contributing to educational equity for ethnic students in Northern Thailand.

\section{DISCUSSION AND CONCLUSION}

\section{The obstacles to creating comprehensive humanization in Thai education}

Our synthesis of the characteristics of a comprehensive human and related study suggests that governmental education management causes obstacles to coexistence in the diverse ethnic communities of Thailand. We focused on Northern Thailand and on ethnic groups in the highlands coexisting with a large number of ethnic lowland people. The obstacles to education management for comprehensive human development fall into the following three aspects: 
1. Obstacles to cognitive development: teaching was unable to promote analytical and cognitive skills in the knowledge application of ethnic diversity.

2. Obstacles to emotional development: teaching did not encourage students to have a positive attitude towards others.

3. Obstacles to behavioral development: teaching was unable to create an understanding of social diversity and so caused discrimination against groups from different ethnicities.

The National Education Management Curriculum of 1960 fostered nationalism and emphasized mainstream culture without mentioning other ethnic peoples. This lack of awareness of human rights and ethnic diversity lasted a long time (Chutintranon, 2014). Additionally, textbooks contained no material about the culture of other ethnic groups, again furthering the educational inequity facing minority ethnic groups. Furthermore, teachers lacked sensitivity to the feelings of children from ethnic minorities. This meant that they were unable to create classrooms and school environments to further coexistence diverse ethnic peoples. The obstacles caused by the instructors were reflected in the student interviews, which found that most teachers did not appear to care about children from ethnic minority communities. All the teachers we surveyed were educated through the basic education curriculum before the additional curriculum in 2014 that began to promote equity for the ethnic groups. Therefore, most teachers lacked awareness of the issue and were unable to manage education that was related to an understanding of ethnic issues.

When discussing multiculturalism, it is important to consider the concept of nationalism. Eoseewong (2004) quotes Benedict Anderson, who maintains that "Nationalism is a form of cultural invention." That is, a nation is not something that occurs naturally, but it arises from the actions of government officials. Thailand is an example of nationalism that has been created through education. The government has undeniably used its educational policies to promote a Central Thai culture and oppress other ethnicities. The education management system is tied to the power of government and so does not facilitate an understanding of ethnicity. Therefore, the education management of teachers could not be as comprehensive as it should be. Government management causes oppression and racial discrimination directly and indirectly, which lead to educational inequity and human rights violations (Anansuchatkul, 2011). Education management must be reviewed to more effectively plan for an educational system appropriate to a multicultural society.

To promote educational equity, our proposals are as follows:

1. The government must investigate the educational inequity facing ethnic groups in the highlands of Northern Thailand. This means allowing ethnic groups to express their own educational needs. Additionally, textbooks need to become more contemporary so that they are appropriate for learning in a multicultural society.

2. The government should encourage more local people to be teachers in local schools to strengthen local pride in identity. Moreover, teaching and learning management should encourage all teachers to learn more about other ethnic groups.

3. Education management should plan to be flexible and to contribute to all ethnic groups. It needs to focus on developing the cognitive, emotional, and behavioral aspects of the whole person. These three aspects are significant for all human development, and a human who develops along these lines will contribute better to his or her society, and to human existence in general (Phra Dhammapitaka, 2013). 
Most crucially, complete human development must account for all ethnic groups. There can be no discrimination between the minority or the majority people of a country. Educational development and the development of the nation can only be furthered by maintaining and furthering equity among all Thai citizens, regardless of their ethnicity.

\section{REFERENCES}

Aekarpornphirom, A. (2016). On-going strategies for promoting youth's mental intelligence-based social identity. Journal of Social Academic, 9(3), 34-50.

Amattayakol, K. (2012). Development of a lifelong learning model based on neo- humanist concepts for sustainable human and society development. Journal of Education Studies, 40(1), 202-207.

Amornvivat, S. (1987). Teaching by creating faith and yonisomanasikara. Bangkok: 21 Century.

Anansuchatkul, B. (2011). Education models for the second generation migrants from Maynmar. Bangkok: The Thailand Research Fund.

Benjakiri, D. (2011). Development of non-formal education activities based on the four noble truths principle to enhance life skills for living together of male inmates in Chiangmai central prison (Doctoral dissertation). Chulalongkorn University. Bangkok.

Boonprasert, W. (2011). Development of a non-formal learning model to enhancen emotional quotients of registered nurses (Doctoral dissertation). Chulalongkorn University. Bangkok.

Chalakbang, W. (2016). The spirituality of teachers: a key characteristic of professional teachers. Journal of Nakhon Phanom University, 6(2), 123-28.

Chalearnsri, S. (2000). Effects of teaching by neo humanist's concept on self-esteem of non-formal distance education learners (Master's thesis). Chulalongkorn University. Bangkok. Retrieved from http://cuir.car.chula.ac.th/handle/123456789/4112

Chutintranon, S. (2014). Nationalism in the Textbook. Bangkok: Matichon.

Dalai, L. (2012). The first dharma talk with Thai people at synagogue. Retrieved from http://www.bia.or.th/ebook/dalailama/THEDALAILAMA.pdf

Eoseewong, N. (2004). Thai nation, Thailand, textbooks and monuments. Bangkok: Ganesha Printing Center Limited.

Faul, M., \& Camacho, K. (2004). Knowledge sharing toolkit: an evolving collection of practical knowledge sharing techniques. Retrieved from https://usaidlearninglab.org/library/ knowledge-sharing-toolkit-evolving-collection-practical-knowledge-sharing-techniques-0

Ganjanapan, A. (n.d.) Multiculturalism in the context of social and cultural change. In the national state and ethnicity. Chiang Mai: Office of Ethnic Affairs Ministry of Social.

Hagen, M., \& Park, S. (2016). We knew it all along! using cognitive science to explain how andragogy works. European Journal of Training \& Development, 40(3), 171-190. https://doi.org/10.1108/EJTD-10-2015-0081

Inthachak, S. (2017). This time that is happy. Journal of Rom phruek, 35(1), 175-184.

Intrarak, C. (2011). Effects of using on instructional with contemplative learning in seminar in academic affairs, Faculty of Education. Prince of Songkla University. Journal of Educational, 2(1), 155-170.

Jatistian, C. (2017). Research and development of in-service teacher training processes in assessing young children based on contemplative education and cognitive coaching. Journal of Education Studies, 45(2), 1-20. 
Kotcharat, J. (2011). Development of a non-formal education activity model using reflective thinking and neo-humanism to enhance life satisfaction for the Youth in Juvenile Vocational Training Center (Doctoral dissertation). Chulalongkorn University. Bangkok.

Kroeksakul, P., Naipinit, A., Na Sakolnakorn, P.T. (2014). Adjustment under Globalization. SKRU Academic Journal, 7(1), 1-12.

Kurian, G.T. (2011). The encyclopedia of political science. Washington: CQ Press.

Kuroda, A. (2014). Contemplative education approaches to teaching teacher preparation program. Procedia -Social and Behavioral Sciences, 166, 1400-1404. Retrieved from http://www. sciencedirect.com/science/article/pii/S1877042814004224

Lawgatok, W., \& Puttasartsattra, P. (2017). Intellectualism: evolution of human resources. Journal of MCU Humanities Review, 3(2), 106-14.

Leelardwattanakit, L. (1999). The follow-up study of trainees who were trained in child development using the neo-humanist approach for application to the pre-school child welfare. Bangkok: Faculty of Social Administration, Thammasat University.

Lodico, M.G., Spaulding, D.T., \& Voegtle, K.H. (2006). Methods in educational research. California: Wiley.

Mahatma Gandhi. (1978). To students. (K. and R. Kusalasai, Trans.). Bangkok: Ketthai.

Mangkhang, C. (2017). Ideology: social studies curriculum for all. Bangkok: Chulalongkorn University Press.

Mansub, S. (n.d.). Equality. Bangkok: King Prajadhipok's Institute.

Mhunnuch, C. (2017). Education for sustainable development. Bangkok: Thanappress Company.

Mills, G.E., \& Gay, L.R. (2019). Educational research: competencies for analysis and applications. Boston: Pearson.

Ministry of Social Development and Human Security. (2016). Master plan for ethnic development in Thailand B.E. 2015-2017. Retrieved from http://www.harvardasia.co.th/wp-content/ uploads/2016/09/503.pdf

$\mathrm{Na}$ ayudhya, A. (2009). Open up intelligent life ideas. Bangkok: Free Mind Publishing Company.

Namdej, N. (2016). Development of nursing practicum instructional process based on experiential learning theory and contemplative education to enhance nursing empathy of nursing students (Doctoral dissertation). Chulalongkorn University. Bangkok.

Namsawat, W., Sriphahon, S., \& Lintharattanasirikun, G. (2015). The effects of using contemplative education to enhance teacher characteristics for students of Rajabhat University, Faculty of Education. Journal of Graduate Studies, 12(57), 7-20.

Nyanasamvara, Somdet Phra. (2017). Education for complete humanity. Samut Sakhon: Pimdee Company.

Office of the Basic Education Commission. (2008). Indicator and strands of social Studies, religion and culture of core curriculum B.E. 2008. Bangkok: Ministry of Education.

Office of the Basic Education Commission. (2014). Guidelines for learning management of citizenship courses. Bangkok: Ministry of Education.

Onganantkun, W. (1989). An analysis of the neo-bumanists concept for human development (Master's thesis). Chulalongkorn University. Bangkok.

Onsri, P. (2014). Contemplative education: education for human development in $21^{\text {st }}$ century. Journal of the Royal Thai Army Nurses, 15(1), 7-11. 
Panditchon, D. (1997). Buddhadasa Bhikkhu's concept of man. Chiang Mai: Graduate School, Chiang Mai University.

Panyapinijnugoon, C. (2012). Effect of contemplative education on transformative learning of Boromarajonani College of Nursing Bangkok's Personnel. Journal of Health and Nursing Research (Journal of Boromarajonani College of Nursing, Bangkok), 28(2), 1-13.

Parnichparinchai, T. (2015). The development of a learning process management based on the application of the contemplative education concept for developing the teachers in basic education. Journal of Humanities and Social Sciences, 21(1), 55-66.

Patton, Q.M. (1980). Qualitative evaluation methods. Beverly Hills, CA: SAGE Publications.

Paul, L.D., \& Ormrod, J.E. (2013). Practical research: planning and design. Boston: Pearson Education.

Pewkam, W. (2010). A case study of learning management model based on contemplative education approach in higher education (Master's thesis). Chulalongkorn University. Bangkok.

Phan-in, P., Rukspollmuang, C., \& Pathumcharoenwattana, W. (2014). Research and Development on learning process for promoting the media literacy for thai youth based on contemplative education. Journal of Education, 42(2), 32-44.

Phoemkhuen, A., Kanya, K., \& Mangkhang, C. (2017). Applying contemplative education to develop student quality in civic duty courses at Darapittayakom School, Uttaradit Province. Journal of Education, Naresuan University, 19(4), 265-275.

Phra Dhammapitaka. (2013). Sustainable development. Bangkok: Komol Kiemthong Foundation.

Phra Maha Vudhijaya Vajiramethi's dharma. (2017). Education for sustainable development. Bangkok: Thanappress Company.

Pitakvongsarogana, S. (1995). Sai Baba's philosophy of education (Master's thesis). Chulalongkorn University. Bangkok.

Pitukthani, A. (2014). Academic review: inequality and unfairness in Thai society. Journal of Social Research, 37(2), 281-292.

Polprasert, A. (2015). Development of a non-formal education program based on the concepts of the noble eightfold path and neo-humanist to enhance moral intelligence for at-risk juveniles (Doctoral dissertation). Chulalongkorn University. Bangkok.

Pongpakatien, J. (2007). Research and development of contemplative education in thai higher education institutions (Doctoral dissertation). Chulalongkorn University. Bangkok.

Ponting, C. (1991). A green history of the world. New York: St. Martin's Press.

Ramalingam, B. (2006). Tools for knowledge and learning: a guide for development and humanitarian organisations. Overseas Development Institute London.

Rattanakul, P. (1971). Socrates and the problem of goodness. Bangkok: Thammasat University Printing House.

Rukpollmueng, C. (2014). Rights and freedoms of basic education: social education and law. Bangkok: Winyuchon.

Rumphakaporn, M.W. (2015). Instruction based on contemplative education concept: a research synthesis. EAU Heritage Journal Social Science and Humanities, 5(2), 328-342.

Saengmani, A. (2008). Contemplative education: education for human development. Journal of Language and Culture, 27(2), 133-138.

Saiphan, P. (2014). Ethnicity and neoliberalism. Bangkok: The Princess Maha Chakri Sirindhorn Anthropology Center. 
Saiphan, P. (2014). The National Liberal Union. Bangkok: The Princess Maha Chakri Sirindhorn Anthropology Center.

Sakulprahm, J. (2011). Development of learning management processes based on contemplative education approach and the optimum experience approach to enhance ability to build teacherchildren relationship. (Doctoral dissertation). Chulalongkorn University. Bangkok.

Sangpithak, W., \& Archapitak, A. (2017). Contemplative education activities and transformative attitude for nursing students. Journal of Health and Nursing Research, 33(2), 159-168.

Sangunpak, C., Phetmalaikut, T., \& Chularut, P. (2014). The results of the development of the program which enhances happiness in learning based on contemplative education for sophomore students of Faculty of Education at Kasetsart University, Bangkhen Campus. Journal of Social Sciences and Humanities, 40(1), 34-53.

Sapprawong, K. (2013). Humanization: is it absolute?. Executive Journal, 33(2), 26-34.

Sartrawut, R. (2001). Rites in the analects as liberation (Master's thesis). Chulalongkorn University. Bangkok.

Sattayopat, S. (2013). Using contemplative study process in general education to develop virtue, morality and needed characteristics for Bachelor's degree students of Chiang Mai Rajabhat University. Journal of Ganesha, 9(1), 1-9.

Singharaj, A. (2009). Development of a work empowerment model for teacher using the neo-humanist concept to develop capacity in learner-centered learning management (Doctoral dissertation). Chulalongkorn University. Bangkok. Retrieved from http://cuir.car.chula.ac.th/handle/ $123456789 / 16747$

Siripunyawong, C. (2007). Development of a non-formal education learning model to enhance mental health by using the principles of neo-humanists and learning contracts (Doctoral dissertation). Chulalongkorn University. Bangkok. Retrieved from http://cuir.car.chula.ac.th/handle/ $123456789 / 16219$

Southeast Asian Ministers of Education Organization. (2010). Teaching competency standards in southeast asian countries: eleven country audit. Philippine: SEAMEO INNOTECH.

Sukumonchan, W. (2010). Human development from amartya sens perspective (Master's thesis). Chiang Mai University, Chiang Mai.

Sumamal, A., \& Thaotho, S. (2018). Development of learning activities enhancing life skills by using contemplative approach on contemplative education course for undergraduate students, Sakon Nakhon, Rajabhat University. Journal of Education, 46(2), 240-259.

Suntonanantachai, T. (2016). The equality, equity and social justice with the social welfare of Thailand. Journal of Law, Huachiew Chalermprakiet University, 7(2), 57-60.

Sutasinobon, K. (2015). Buddhist teaching and learning for moral development for students. Bangkok: Commercial World Media.

Suvarnakuta, P. (2014). Development of a non-formal education activity model to enhance global citizenship of thai children and youth (Doctoral dissertation). Chulalongkorn University. Bangkok.

The Earth Charter. (2018). Values and principles to foster a sustainable future. Retrieved from http://earthcharter.org/discover/the-earth-charter.

Theerawongnukul, H. (2013). The development of a program to enhance self-esteem and social skills for non-formal education students (Doctoral dissertation). Chulalongkorn University. Bangkok. 
Tiacharoen, S. (2012). Human resource management with contemplative education. Journal of Educational Administration, 3(1), 173-184.

UNESCO. (2015). Global citizenship education topics and learning objective. Paris: UNESCO.

UNESCO. (n.d.) Education and cultural diversity. Retrieved from http://unesdoc.unesco. org/ark/:48223/pf0000125205.

United Nations, International Convention on the Elimination of All Forms of Racial Discrimination. (2011). First to third periodic reports of States parties due in 2008 Thailand. Retrieved from http//:www.jba.tbs.tu.ac.th/files/APAStyle.pdf

Ungpakorn, P. (2016). Educational views. Bangkok: Thammasat University Press.

Wattanaburanon, A. (2016). Development research of love model for enhancing comprehensive humanization: a research program for higher education students. Bangkok: O.S. Printing House.

Weerakul, N. (2011). Development of a non-formal education program using neo- humanist concept to enhance ethics in caring for the elderly for the care for the elderly at home volunteers (Doctoral dissertation). Chulalongkorn University. Bangkok.

Young, R., \& Asian Productivity Organization. (2010). Knowledge management tools and techniques manual. Tokyo: Asian Productivity Organization. 


\section{APPENDIX}

Theoretical concepts: See Sartrawut, 'Rites in the Analects as Liberation', p.1, 3, 10, 13, 18, 24. And 'Table 1' about Contemplative education researchers, Andragogy researchers, Neohumanist researchers.

Monks: Include Thich Nhat Hanh, Phutthathat Phikkhu, Phra Dhammapitaka, Phra Maha Wudhijaya Vajiramethi, Phra Nyanasamvara; See Inthachak, "This Time That is Happy", p. 175-184; See Amornvivat, 'Teaching by creating faith and Yonisomanasikara', p. 21-22; See Polprasert, 'Development of a Non-Formal Education Program Based on the Concepts of the Noble Eightfold Path and Neo-Humanist to Enhance Moral Intelligence for At-Risk Juveniles', p.6-8,32-33,50; See Chalakbang, 'The Spirituality of Teachers: A Key Characteristic of Professional Teacher', p.123-128; See Lawgatok \& Puttasartsattra, Intellectualism: Evolution of Human Resources, p.106-114; See Panditchon, 'Buddhadasa Bhikkhu's Concept of Man', p.1-9,35-39; See Sukumonchan, 'Human development from Amartya Sens perspective', p.6; See Phra Dhammapitaka, 'Sustainable development', 226227; See Natnutda, 'Education for human excellence of Sathya Sai school', p.21-21; See Phra Maha Wudhijaya Vajiramethi's dharma, 'Education for sustainable development', p.48; See Somdet Phra Nyanasamvara, 'Education for complete humanity', p.80.

Philosophers \& Spiritual leaders: Include: Dalai Lama, Mahatama Gandhi, Sai Baba, Socrates. See Dalai Lama, 'The First Dharma Talk with Thai People at Synagogue', p.13-29; See Gandhi, 'To students', p.77; See Phumaree, 'Gandhi, throug 'The Will to Power' the Concept of Nietzsche's', p.88-93; See Pitakvongsarogana, 'Sai Baba's philosophy of education', p.11, 13, 15, 30; See Rattanakul, 'Socrates and the Problem of Goodness', p.35.

Developers: Include: King Bhumibol Adulyadej and Amartya Sens. See Somvang and Jiratat, Education for sustainable development, p.70-73; See Pewkam, 'A Case Study of Learning Management Model Based on Contemplative Education Approach in Higher Education', p.1; See Sukumonchan, 'Human development from Amartya Sens perspective', p.4-5,9,5759.

Scholars: Include: Jumsai $\mathrm{Na}$ ayudhya, Amornvivat, Piriyanuwat and Rattanamaneechat, Mhunnuch, Ungpakorn, Sutasinobon, and Gomes de Matos. See Jumsai Na ayudhya, 'Open up intelligent life ideas', 27. See Saengmani, 'Contemplative Education: Education for Human Development', 136. See Amornivivat, 'Teaching by creating faith and Yonisomanasikara', 21-22. See Piriyanuwat and Rattanamaneechat, 'Education for sustainable development' 71. See Mhunnuch, 'Education for sustainable development', 9697. See Ungpakorn, 'Educational views', 3-4. See Sutasinobon, 'Buddhist teaching and learning for moral development for students', 8-10 and 13-19. See Sapprawong, 'Humanization: Is It Absolute?' 29.

Contemplative education researchers: Include: Wattanaburanon (2016), p.185; Saengmani (2008), p.136; Sumamal \& Thaotho (2018), p.240-243, 245-247; Kuroda (2014), p.14001404; Phoemkhuen (2017), p.265-268,271-274; Aekarpornphirom (2016), p.34-50; Jatistian (2017), p.4,13-16; Sangunpak el al. (2014), p.37-39,48-51; Intrarak (2011), p.155, 167-169; Panyapinijnugoon (2012), p.1-4; Pongpakatien (2007), p.5-7,11-17; Sakulprahm, (2011), p.8-15; Rumphakaporn (2015), p.328-332; Namdej (2016), p.10,59-62; Phan-in 
et al. (2014), p.32,35, Onsri (2014), p.7-10 , Tiacharoen (2012), p.180,183; Sattayopat (2013), p.6-8; Parnichparinchai (2015), p.55,57,61-65; Namsawat et al. (2015), p.7,9-10,1618, Sangpithak \& Archapitak (2017), p.159,162-167, Pewkam (2010), p.10-15.

Andragogy researchers: See Hagen and Sunyoung, "We knew it all along! Using cognitive science to explain how andragogy works", p.171-190; See Jennings et al., Partnering for real world learning, sustainability and tourism education, p.378-394; See Kuroda, 'Contemplative Education Approaches to Teaching Teacher Preparation Program’, p.1400- 1404.

Neo-humanist researchers: Include: Onganantkun (1989), p.38, Weerakul (2011), p.6-8, Singharaj (2009), p.11, 79, Siripunyawong (2007), p.8-14, 38-41, Chalearnsri (2000), p.69, 15-23, Kotcharat (2011), p.6-17, 59-61, Amattayakol (2012), p.202-205, Benjakiri (2011) p.8-13, Leelardwattanakit (1999), p.20-22, Theerawongnukul (2013), p.13, 34-38, Polprasert (2015), p.6-10, 38-42, Boonprasert (2011), p.14-17, 69-73, Suvarnakuta (2014), p.11-13, 53-56. 